\title{
Viessuoje Mujttuo: Saving an Indigenous Language through New Technology
}

\section{Oscar Sedholm}

The Ume Sami language is an Indigenous language that stretches from the Baltic Sea, across Sweden and Norway to the Norwegian Sea. Before colonisation it was one of several dominant languages spoken in northern Scandinavia. Due to colonisation efforts, nationalistic policies and racism, the language has now been decimated to roughly below 50 known native speakers.

Ume Sami has yet to be formally accepted as a 'proper' minority language in Sweden (instead being considered a dialect by some) and it lacks a formalised orthography - that is, formal rules of how to write and spell the language. The process of becoming accepted into both the general Sami community and the nations of Sweden and Norway has been a long process that has only recently started to yield gains. ${ }^{1}$

With fewer than 50 remaining speakers of the language, the situation is dire. Most of these speakers are Elders and fewer remain for each year that passes. The speakers are spread out over an area roughly the size of

1 Editors' note: The Ume Sami language was recognised in April 2016 by the Samiskt Parlamentariskt Råd (SPR), a council that consists of representatives from all three national Sami parliaments (Påve 2016). 
mainland Britain. Most speakers do not meet other Ume Sami speakers more than once a week, which means that Ume Sami cannot effectively be used as their primary language.

Under these conditions it is tough to not only to organise the Ume Sami community, but also to have new pupils learn the language. Today there is no formal education option to educate Ume Sami teachers. There is also a lack of proper learning materials, with no textbooks, no dictionary and no media produced in Ume Sami. Currently, there are only two Ume Sami videos on the popular video platform YouTube: both are songs produced to teach Ume Sami words.

The Såhkie Umeå Sami Association (based in Umeå, Sweden) together with the Ume Sami language association Álgguogåhtie decided to start a cooperation to try and save the Ume Sami language from extinction. The Swedish state has a few initiatives to help preserve minority languages, but Sami language projects are at this time 'laughably underfinanced', to quote a minority coordinator that works with Ume Sami. To solve the aforementioned problems, the project Viessuoje Mujttuo (Living Memory in Ume Sami) was started. Utilising the free online learning platform Memrise, Viessuoje Mujttuo set a goal of gathering words and phrases to be put together into an interactive learning experience, available for free for everyone with an Internet connection. Memrise uses an easily worked system of lessons and memorisation that helps users both learn how to spell words as well as pronounce them (if the creator has added sound). Pictures and video footage can also be added to the lessons for extra flavour.

An initial beginner's lesson of 250 words was recorded and put together by the Såhkie Umeå Sami Association in the spring of 2014, and during that summer Viessuoje Mujttuo was organised by contacting both Álgguogåhtie and Memrise. Whilst the summer was spent applying for funds (Sweden has a rather advanced system of applying for municipal, regional and state funding for NGO and nonprofit projects, instead of charity fundraising), the project itself took flight in late autumn of 2014 with the goal of creating broader digital learning material and arranging a conference with international visitors from Memrise in late 2014.

A goal was set that the new lesson would include roughly 1,000 different words and phrases with the possibility of gradually adding more after the conference. Memrise sent us a general list (in English) of words that were 
to be used in their new video function for the platform, where short video clips were meant to enhance the learning experience by not only adding something more memorable to look at, but also showing a user of the language in his or her cultural setting. The idea behind these clips is that normal people would easily be able to record them on the fly through their smartphones, wherever they may find themselves, and then easily add them to the platform.

We suffered a number of setbacks due to bad communication when trying to work with the word list. Some of the people we recruited to work with the word list opted out of the project work without informing us, which meant that in the end the word list had to be hastily translated over the course of a week. Optimally, the list would have been gradually translated, grammatical explanations added to different sections, and unsuitable words and phrases replaced by something more useful to the Ume Sami community. The list was translated in the end, but with great stress put on the project group and our contacts.

Our deal with Memrise, beyond the opportunity to work on something very interesting together, would be to attain positive attention to our common work. We kept our operation on a nonprofit basis at all times, and all footage and learning materials produced during our project was to remain the property of the Sami community through our associations, with Creative Commons licence giving Memrise rights to use the material. After the word list had been completed, our visitors from Memrise arrived together with journalist Holly Young from The Guardian. We set out on a road trip across the Ume Sami area to both record words and phrases on the spot, as well as to give Holly Young the opportunity to learn about Ume Sami and Sami culture. In the end, we managed to meet around 10-15 Ume Sami speakers, and record a few of them.

Due to the time limit, it was soon obvious that we would not be able to produce the material right there and then. Instead, the week became more of an introduction to the project itself, where we learned more about what was needed to take the project further. Working relations were established between the partners of the project as well as the Ume Sami community. That week culminated in the conference itself, which gathered around 15-20 participants for a day to introduce the project, and realise the opportunities at hand. Afterwards, an article was published in The Guardian, which garnered a lot of attention around Christmas 2014 (Young 2014). 
We are currently looking for new funds to continue the project, which will mean local recording out in the Ume Sami area for parts of 2015. Hopefully this will mean that both Swedish and English speakers will be able to learn some Ume Sami for free over the internet with sound, video and spelling, by the start of 2016 .

\section{References}

Påve, Marja. 2016. 'Umesamiskan godkänns som eget skriftspråk' [The Ume Saami language approved as an official written language]. SVT Nyheter. Online: www. svt.se/nyheter/lokalt/vasterbotten/umesamiskan-godkanns-som-eget-skrift sprak (accessed 28 June 2018).

Young, Holly. 2014. 'Reindeer herders, an app and the fight to save a language'. The Guardian. Online: www.theguardian.com/education/2014/dec/22/-spreindeer-herders-an-app-and-the-fight-to-save-a-language (accessed 28 June 2018). 
This text is taken from Indigenous Efflorescence: Beyond Revitalisation in Sapmi and Ainu Mosir, edited by Gerald Roche, Hiroshi Maruyama and Åsa Virdi Kroik, published 2018 by ANU Press, The Australian National University, Canberra, Australia. 